УДК 159.923 / 928

Кулакова Лариса

кандидат психологічних наук, доцент кафедри вікової та педагогічної психології

ORCID iD: 0000-0001-6496-7964.

Кулаков Руслан

кандидат психологічних наук, доцент кафедри вікової та педагогічної психології Рівненського державного гуманітарного університету ORCID iD: 0000-0003-0033-8784. DOI https://doi.org/10.35619/prap_rv.vi13.124

\title{
ШЛЯХИ ФОРМУВАННЯ ПОЧУТТЯ ВЛАСНОЇ ГІДНОСТІ ОСОБИСТОСТІ В ОНТОГЕНЕЗІ
}

Анотація. У статті з позицій сучасних теоретико-прикладних наукових досліджень висвітлюється проблема психологічного феномену особистісної гідності як складової моральної свідомості. У статті систематизовано численні характеристики гідності як найважливішої моральної якості, інтегративності людської реальності, вищої цінності. Визначено, як на державному рівні декларується гідність людини ї̈ захист у правовому полі. Здійснено аналіз останніх досліджень проблеми формування почуття власної гідності особистості у вітчизняній та зарубіжній психології. Визначено основні аспекти прояву почуття власної гідності особистості, а саме: як психологічний феномен і як особистісна диспозиція. Здійснено аналіз основних факторів, щзо впливають на формування у дитини самоповаги, адекватної самооцінки та почуття власної гідності (сім'я, батьки, соціальне оточення i т.д.). Зокрема, основну увагу зосереджено на важливості впливу дорослих та сочіального оточення на формування цього психологічного конструкту. Встановлено основні етапи становлення почуття власної гідності дитини на прикладі піраміди основних потреб людини Маслоу.

Ключові слова: гідність, почуття власної гідності, моральна самосвідомість, особистість, дорослі, батьки, сочіальне оточення.

Постановка проблеми. Глибинні перетворення у всіх сферах життя країни докорінним чином змінили систему вимог суспільства до особистості. Це надає ще більшої гостроти проблемам, що пов'язані із моральним розвитком. Особливо важливим є вивчення особливостей моральної сфери у дитячому віці, коли закладаються основи моральної саморегуляції, інтенсивно розвиваються всі елементи моральної свідомості (Павелків, 2009, c. 5).

Гідність - це одна із найскладніших складових моральної свідомості, внутрішнього світу людини, що проявляється в усіх галузях діяльності та суспільних відносинах.

Гідність є одним з ключових понять Конституції України (ст. 3, 21, 28, 41, 68, 105). В ній, зокрема, визнано гідність однією 3 «найвищих соціальних цінностей» в Україні (ст. 3), задекларовано, що «усі люди є вільні і рівні у своїй гідності та правах» (ст. 21) та що «кожен має право на повагу до його гідності» (ст. 28). Гідність громадян охороняється Цивільним кодексом України та Кримінальним кодексом України, зокрема у Цивільному кодексі України:

- гідність визнано особистим немайновим благом (ст. 201);

- задекларовано право на повагу і недоторканність «гідності та честі» фізичних осіб (ст. 297, пП. 1, 2);

- зафіксовано право фізичних осіб звернутися до суду з позовом про захист їх гідності та честі (ст. 297, п. 3); 
- приниження «честі та гідності фізичної особи» визнано моральною шкодою, яка підлягає відшкодуванню (ст. 23).

Гідність - особлива цінність суб'єкта, яка може бути вивчена завдяки властивостям своєї природи. Це почуття полягає в неприйнятті особистістю асоціальних дій (відмові від таких вчинків) і спрямованості на здійснення моральних (гідних) учинків (за умови наявності усвідомленої вольової саморегуляції). Сприйняття людини, як носія гідності, означає ціннісне ставлення й повагу до неї, визнання ії прав, а також високу вимогливість. Гідність можна розглядати як диспозицію, інтегральну рису, що представлена складним утворенням внутрішнього світу особистості й постає через усвідомлення індивідом власних можливостей, прагнення до самореалізації й саморозвитку. Почуття власної гідності проявляється в емоційному переживанні - ставленні до себе й інших як до цінності.

Зайцева почуття власної гідності розглядає в двох аспектах: психологічний феномен і особистісна диспозиція, тобто схильність поводити себе згідно з усвідомленням власної гідності та гідності іншої людини. Таким людям притаманні високій рівень розвитку моральності - післяконвенційний рівень моральної свідомості; гуманність чи «людяність» ставлення до людини як до більш значущої цінності, ніж збереження моральних норм та принципів; внутрішня відповідальність особистості; тяжіння до самореалізації. Дослідницею доведено, що специфіка «почуття власної гідності», як особистісної диспозиції, полягає в необхідному поєднанні високого рівня розвитку трьох компонентів: когнітивного усвідомлення безумовної цінності людини, що виявляється в моральному ставленні до іншого; емоційного - переживання власної цінності як безумовної, високий рівень самоповаги; конативного - стійкої реалізації даних відносин у поведінці, високого рівня саморегуляції (2003, c. 23).

Розв'язання практичних завдань моральності - ціннісного ставлення до іншої людини, формування почуття власної гідності як найважливішого конструкту самосвідомості обумовлюють важливість окресленої проблематики саме в теперішній історичний момент, коли відбуваються радикальні зміни світоглядних і ціннісних основ суспільства.

Аналіз останніх досліджень 3 проблеми. У психологічній науці природа гідності людини висвітлюється через: самоставлення (Бех, Колишко, Роджерс, Рубінштейн, Сарджвеладзе, Чеснокова та ін.); інтегровану самооцінку (Бандура, Вагнер, Джеймс та ін.); самоцінність й самоповагу (Кулі, Маралов, Савельєв, Сафін та ін.); моральну самосвідомість (Боришевський, Братусь, Булах, Павелків, Столін та ін.).

У світовій психологічній науці різні аспекти почуття власної гідності розглядали Кулі (через структуру «дзеркального Я»), Оллпорт (специфіка зрілості особистості), Маслоу (в рамках потреб особистості), Роджерс (через самоприйняття особистості), Хетті (самоставлення особистості), Каган (висвітлює гідність особистості), Якобі (самоцінність особистості), Шибутані (визначає критерії почуття власної гідності). Вітчизняні вчені (Бех, Булах, Боришевський, Колесник, Рибалка та ін.) у своїх дослідженнях звертаються до людської гідності, особливостей розвитку почуття власної гідності в онтогенезі особистості як структурної одиниці самоставлення й підгрунтя поваги до себе; детермінанти моральності особистості, котра пов'язана із самооцінюванням, мотивації щодо самоудосконалення й духовної передумови, що попереджає моральні конфлікти. На підгрунті теоретичного аналізу наукових досліджень з філософії, педагогіки та психології почуття власної гідності переважно розглядається як вид самоставлення (Бех, Кравченко); феномен усвідомлення власної самоцінності (Рибалка); моральна чеснота (Павелків, Савельєв); цінність людини (Юрій); складова самосвідомості (Столін). Також зазначимо, що гідність постає як суттєва складова самосвідомості особистості (Булах, Кадол, Малахов); складне інтегративне особистісне утворення (Коротковських, Шишмакова); емоційно-ціннісне ставлення (Смузова). Але питання впливу соціального оточення, стилю родинного виховання на формування гідності особистості лишається маловивченим.

Мета статті. Здійснити аналіз феномену почуття власної гідності особистості як одного 3 найважливіших конструктів моральної самосвідомості особистості; визначити особливості та шляхи формування почуття власної гідності дитини в онтогенезі .

Виклад основного матеріалу дослідження. Почуття власної гідності - це прийняття 
себе як значущої людини, не порівнюючи себе з іншими. Ця моральна якість передбачає наявність внутрішньої впевненості. Людина 3 розвиненим почуттям власної гідності має адекватну самооцінку, просоціальну позицію, дозволяє собі чинити так, як ій диктують власні переконання. «Тільки розуміння і прийняття свободи вибору дозволяє людині переходити від просоціальних типів поведінки до моральних вчинків». (Павелків, Корчакова, 2013 , с. 38).

Почуття власної гідності не дається людині від народження. Хто ж і як може вплинути на формування гідності людини в онтогенезі? Незаперечним є той факт, що першим соціальним оточенням дитини є сім'я. Саме із родини починається розвиток кожної людини. У дитини, що зростає у теплій та дружній сімейній атмосфері, ще з раннього віку зароджуватимуться впевненість у собі, у своїх власних силах та можливостях, уміння долати труднощі. А це $\epsilon$ основою формування почуття власної гідності особистості. Відомий вітчизняний педагог Сухомлинський зазначав: «У людському світі безліч чеснот, але одна чеснота $є$ вершиною людяності - це почуття власної гідності» $(1976$, с. 113). На розвиток почуття поваги дитини до самої себе впливають такі фактори: вплив батьків та найближчих родичів; вплив найближчого оточення поза межами сім'ї, до якого належать друзі, однокласники і т.д. Слід зауважити, що позитивний досвід такої взаємодії підніматиме самооцінку дитини, а негативний, навпаки, - знижуватиме ії. Як же ж формується почуття власної гідності людини в онтогенезі? I яка роль дорослих у цьому процесі? Спробуємо відобразити це за прикладом піраміди потреб Маслоу. У 1943 р. в вчений представив головні людські потреби у вигляді декількох рівнів - від більш простих до більш складних. До задоволення потреби, що знаходиться рівнем вище, можна перейти тільки після того, як буде задоволена та, що знаходиться рівнем нижче. Ієрархія потреб складалася 3 п'яти рівнів (Маслоу, 2008, с. 185).

1 етап формування почуття власної гідності - «Фізіологічні потреби». Від піклування батьків залежить психологічний та фізичний стан дитини. Саме від них дитина отримує те, що їй необхідно у цей період: їжу, тепло, чисту білизну, турботу. Тобто мама стає для дитини основним джерелом отримання приємних відчуттів. I їх забезпечення стає основою формування власного «Я - задоволений» малюка. Друга половина немовлячого періоду засвідчить трансформацію цього «Я»: своїм плачем малюк закликає маму робити лише так, як йому подобається. Дитина уже чітко знає, що їй подобається, а що - ні, що вона любить, а що - ні. Для дитини першочерговим завданням $є$ досягнення власного блага.

У випадку, коли дитина не отримує материнської турботи, буде формуватися «Я мені погано». Звичайно, це матиме негативні наслідки у психічному розвитку дитини. Дуже часто у таких діток зникає апетит, інтерес до навколишніх подій, з'являється тривожність.

2 етап формування почуття власної гідності - «Безпека і стабільність». Але для того, щоб дитина сама себе полюбила, одних лише позитивних почуттів мало. Дитина повинна полюбити своє тіло. Слід вчити малюка правильно реагувати на травми. Якщо дитина, отримавши травму, не звертається за допомогою до дорослих, то це може свідчити про те, що у неї не розвивається здатність піклуватися про себе. Важливо навчити дитину відрізняти серйозну небезпеку від незагрозливої, вміти стійко переносити незначний біль. Саме так у дитини закладаються основи турботи про себе без сторонньої допомоги.

Чи не найважливішим завданням батьків є завдання навчити дошкільника піклуватися про власну безпеку (не торкатися до гарячих електропристроїв, не брати гострих предметів і т.ін.). Хоча не слід при цьому залякувати дітей. Адже вони можуть відчувати невиправданий страх до будь-яких абсолютно безпечних предметів. Також важливо навчити дитину піклуватись про своє здоров'я. Дитина повинна полюбити своє «хворе тіло», коли занедужає. Малюк повинен розуміти, як піклуватись про хворе горло, вухо і т.ін. Дитині варто знати про функції статевих органів. Якщо дитина полюбить себе як хлопчика чи як дівчинку, вона набагато легше впорається 3 проблемами статі в підлітковому віці. В майбутньому це позбавить дитину від багатьох сексуальних проблем.

3 етап формування почуття власної гідності - «Сочіальні потреби». Усі діти хочуть бути схожими на своїх батьків. Саме тому батьки самі повинні відповідати тим вимогам, які 
вони висувають до дитини. Навчити дитину бути ввічливим, стежити за чистотою, дотримуватись правил особистої гігієни можна лише власним прикладом. Також батьки повинні правильно оцінювати самостійність своєї дитини. Йдучи від маленької мети до більш складної і домагаючись спільного успіху, мами і тата будуть розвивати в дитині цілеспрямованість, терпіння, а найголовніше - зміцнювати свій зв'язок 3 дитиною і його індивідуальне почуття власної гідності. Ніщо так не зміцнює почуття власної гідності, як усвідомлення досягнення високої мети під час виконання складного завдання.

4 етап формування почуття власної гідності дитини - «Самоствердження». Дитину потрібно хвалити, захоплюватися іiі досягненнями. Якщо дитина відчуває, що батьки пишаються нею та радіють іï успіхам, то вона прагнутиме зробити щось ще краще, аби доставити задоволення і батькам, і собі. Обов'язково слід щиро захоплюватися дитиною, коли вона здійснила достойний вчинок., поважати іiі, фіксувати її позитивні риси характеру, дозволяти бути такою, якою вона $є$. Тільки тоді дитина буде усвідомлювати власну цінність та буде впевнена у ній. Батьки повинні розвивати у дітей інтерес до отримання нових знань, формування нових умінь. Це дасть можливість дитини вірити у свої сили та рухатись у своєму розвитку вперед. Батьківське заохочення дає дитині відчуття власної значущості, а

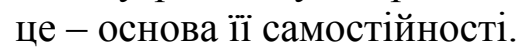

5 етап формування почуття власної гідності - «Самоповага». Формування почуття власної гідності дитини залежить від почуття власної гідності їі батьків. Адже дитина - це дзеркальне відображення тата i мами. Ставлення дорослих до дітей визначає модель поведінки, яку діти будуть втілювати у своєму житті. Навчити дитину бути гідною - означає самому дути таким. Діти копіюють не лише поведінку, але і моральні принципи дорослих. Чоловік і жінка стають справжніми батьками, коли вважають своїх дітей власним продовженням. За таких обставин дитина - це фундамент їх почуття власної гідності. Тому одним із найважливіших і найважчих завдань батьків - дозволити дитині бути самою собою, $\mathrm{i}$ не намагатися здійснити за свої нездійснені мрії за рахунок дитини, тобто не вважати дитину «своєю власністю». Також на формування почуття власної гідності дошкільника впливають ровесники, друзі. Дитина, яка користується авторитетом та повагою однолітків, зростає впевненою у собі особистістю. Але якщо дитина в дитинстві зазнавала принижень, або ж насильства, то вона буде позбавлена можливості формування адекватного образу «Я». Таким чином, можна ствердно зазначити, що почуття гідності людини проявляється вже у ранньому дитинстві, і значною мірою залежить від оцінки дій та вчинків дитини авторитетними дорослими. Культура гідності проявляється у ситуаціях відстоювання власної честі.

Висновки і перспективи подальших розвідок. Генезі дитячого почуття власної гідності сприяе позитивна оцінка оточуючими людьми відповідних чеснот дитини. Формування адекватної самооцінки виражається в появі у дитини потреби в оцінці своєї діяльності з боку дорослих. Подальші перспективи у вивченні цієї проблеми вбачаємо у розробці психологічних заходів, розвивальних занять, що сприятимуть психологічному супроводу почуття власної гідності дитини, профілактиці негативних проявів, пов'язаних із маніпулюваннями свідомістю, а також сприяння особистісному становленню дитини.

\section{СПИСОК ПОСИЛАНЬ}

Зайцева, Ю. (2003). Чувство собственного достоинства как психологический феномен. (Дис. канд. психолог. наук.). Санкт-Петербургский государственный университет. СанктПетербург.

Конституція України (2019). Київ: ЦУЛ.

Кримінальний кодекс України (2001). Відомості Верховної Ради України.

Маслоу, А. (2008). Мотивация и личность. Санкт-Петербург: Питер.

Павелків, Р., Корчакова, Н. (2009). Феноменологія морального розвитку особистості: детермінація, механізми, генезис. Рівне: Волинські обереги.

Павелків, Р., Корчакова, Н. (2013). Просоціальний розвиток особистості. Рівне: О. Зень.

Сухомлинський, В. (1976). Вибрані твори ( Т. 2). Київ: Радянська школа.

Цивільний кодекс України (2003). Відомості Верховної Ради України, Ст. 40-44, 25-26.

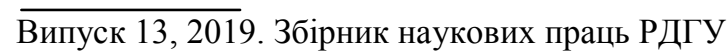




\section{REFERENCES}

Zaytseva, Yu. (2003). Chuvstvo sobstvennogo dostoinstva kak psikhologicheskiy fenomen [Selfesteem as a psychological phenomenon]. (Dis. kand. psikholog. nauk). Saint-Petersburg State University. Sankt-Peterburg. [in Russian].

Konstytutsiia Ukrainy (2019). [Constitution of Ukraine]. Kyiv: TsUL. [in Ukrainian]. [in Ukrainian].

Kryminalnyi kodeks Ukrainy (2001). [Criminal Code of Ukraine]. Vidomosti Verkhovnoi Rady Ukrainy. [in Ukrainian].

Maslou, A. (2008). Motivatsiya i lichnost [Mortation and personality]. Sankt-Peterburg: Piter. [in Russian].

Pavelkiv, R., \& Korchakova, N. (2009). Fenomenolohiia moralnoho rozvytku osobystosti: determinatsiia, mekhanizmy, henezys [Phenomenology of moral development of hersonality: determination, mechanisms, genesis]. Rivne: Volynski oberehy. [in Ukrainian].

Pavelkiv, R., \& Korchakova, N. (2013). Prosotsialnyi rozvytok osobystosti [Prosocial personality development]. Rivne: O. Zen. [in Ukrainian].

Sukhomlynskyi, V. (1976). Vybrani tvory [Selected works] (T. 2). Kyiv: Radianska shkola. [in Ukrainian].

Tsyvilnyi kodeks Ukrainy (2003). [Civil Code of Ukraine]. Vidomosti Verkhovnoi Rady Ukrainy, St. 40-44, 25-26. [in Ukrainian].

\section{WAYS OF FORMING OF PERSONAL SELF-ESTEEM IN ONTOGENESIS}

Larysa Kulakova

Candidate of Psychological Sciences, Associate Professor of Department of Lifespan \& Pedagogical Psychology

ORCID iD: 0000-0001-6496-7964.

Ruslan Kulakov

Candidate of Psychological Sciences, Associate Professor

Department of Lifespan \& Pedagogical Psychology

Rivne State University of the Humanities

ORCID iD: 0000-0003-0033-8784.

DOI https://doi.org/10.35619/prap_rv.vi13.124

Annotation. The article deals with the psychological phenomenon of the personal selfesteem as a component of moral consciousness from the perspectives of modern theoretical and applied scientific researches. In the article it has been systematizes numerous characteristics of dignity as the most significant moral quality, that integrated the human reality, and considered to be of the highest value. It has been determined how the individual self-esteem is declared to be protected legally by the state (Constitution of Ukraine, Civil Code of Ukraine, and Criminal Code of Ukraine). The recent studies concerning the forming of personal self-esteem in the domestic and the foreign psychological sciences have been analyzed. The main aspects of the display of the personal self-esteem have been defined, in particular: as a psychological phenomenon and as an individual disposition. The main factors that influence the child's self-esteem, adequate selfappraisal and self-dignity (a family, parents, social environment, etc.) have been determined. Furthermore, the attention was focused on the importance of adults' influence and the social environment in the process of forming of this psychological construct. The basic stages of the forming of a child's self-esteem are illustrated on the example of A.Maslow's pyramid of hierarchy of needs: physiological needs, safety and stability, social needs, self-dignity, self-respect of a personality. The prospects of the further scientific explorations of the formation of the personal selfesteem have been outlined.

Key words: dignity, self-esteem, moral self-consciousness, personality, adults, parents, social environment. 